\title{
ALIH FUNGSI HUNIAN MENJADI KOMERSIAL DAN KENYAMANAN BERMUKIM DI BINTARO SEKTOR 9 TANGERANG SELATAN
}

\author{
Ambayu Gracia Cintyarani', Rizon Pamardhi-Utomo ${ }^{1}$, Nur Miladan ${ }^{1}$ \\ ${ }^{1}$ Perencanaan Wilayah dan Kota, Fakultas Teknik, Universitas Sebelas Maret
}

\begin{abstract}
Abstrak
Alih fungsi hunian menjadi komersial merupakan hal yang tidak dapat dihindari dari pertumbuhan kota untuk memenuhi kebutuhan masyarakat. Pergeseran fungsi yang terjadi di Bintaro Jaya masih terus terjadi hingga saat ini dan belum menunjukkan adanya tandatanda penurunan. Dampak alih fungsi hunian menjadi komersial di lingkungan perumahan yang dirasakan oleh masyarakat adalah ketidakserasian fungsi, kepadatan lalu lintas, penurunan privasi dan kualitas lingkungan. Penelitian ini dilakukan untuk melihat tingkat kenyamanan bermukim masyarakat Bintaro Sektor 9 setelah adanya alih fungsi hunian menjadi komersial, yang dilihat dari kompatibilitas, aksesibilitas, privasi dan kualitas lingkungan. Penelitian dilakukan dengan metode kuantitatif, berupa data yang terukur menggunakan kuesioner. Selanjutnya hasil kuesioner dianalisis dengan teknik skoring untuk melihat kecenderungan gangguan yang dirasakan. Berdasarkan hasil analisis dapat diketahui bahwa tingkat kenyamanan bermukim masyarakat adalah rendah. Untuk menghindari adanya penurunan tingkat kenyamanan lebih jauh lagi, perlu adanya pengendalian pembangunan komersial dengan peraturan zonasi.
\end{abstract}

Kata kunci: alih fungsi; kenyamanan bermukim; komersial

\section{Abstract}

Land conversion from residential to commercial is unavoidable in certain areas due to high urban growth process that needs to accommodate community's demands. Land conversion from residential to commercial uses that occurred in Bintaro Jaya is incrasingg until now and has not shown a downward trend. The impact arising from land conversion that is suffered by community $e$ are incompatibility of functions, traffic congestion, decreased privacy and environmental quality. This research was conducted to see the level of living comfort in the Bintaro Sector 9 community after the change of residential function to commercial use, as seen from compatibility, accessibility, privacy and environmental quality. The research implemented a quantitative method with questionnaire. Furthermore, the results of the questionnaire that have been obtained from the housing community is analyzd with scoring techniques. This analysis is carried out to see the tendency of the perceived disturbance. Based on the results of the analysis, it can be considered that the comfortabiity level of living of the community is low In order to avoid a further decrease in comfort level, it is necessary to control commercial development with zoning regulations.

Keywords: land conversion, commercial, living comfort

\section{PENDAHULUAN}

Permintaan yang tinggi akan tempat bermukim yang nyaman mendorong pembangunan perumahan di pinggiran kota yang harganya lebih rendah dibanding lahan di pusat kota (Budiharjo, 1987). Pada 1979, Bintaro Jaya dikembangkan untuk memenuhi kebutuhan hunian bagi masyarakat Jakarta dan sekitarnya, namun seiring berjalannya waktu masyarakat melihat adanya potensi untuk membuka usaha dan memenuhi kebutuhannya. Kawasan komersial dicerminkan sebagai bentuk aktivitas perdagangan yang memiliki pengaruh besar pada kegiatan ekonomi kota. Kegiatan komersial terus berkembang ke arah luar daerah perkotaan dan mendesak permukiman. Alih fungsi hunian menjadi komersial di Bintaro Jaya sudah terjadi selama 20 tahun. Perubahan fungsi hunian terjadi di bagian luar perumahan atau sepanjang jalan utama yang menjadi jalan penghubung antar kota.

Berdasarkan hasil wawancara dengan masyarakat, komersial yang ada pada kawasan saat ini belum memiliki izin usaha dan masih menggunakan izin rumah tinggal, sehingga bangunan pertokoan di kawasan bersifat tidak resmi. Perubahan fungsi hunian menjadi komersial tersebut menimbulkan permasalahan dalam beberapa aspek yang mempengaruhi kenyamanan bermukim, yaitu kompatibilitas, aksesibilitas, privasi dan kualitas lingkungan. Berdasarkan hasil eksplorasi, fenomena serupa, yaitu alih fungsi lahan perumahan menjadi komersil pernah terjadi di beberapa 
wilayah di Indonesia. Beberapa wilayah yang mengalami alih fungsi lahan perumahan menjadi komersial adalah Pondok Indah dan Kemang di Jakarta Selatan dan kawasan Tlogosari di Semarang. Dari ketiga kawasan tersebut hanya Pondok Indah yang berhasil mempertahankan fungsinya sebagai perumahan dan membatasi kawasan yang dapat dikembangkan untuk kegiatan komersial, sedangkan Kemang dan Tlogosari menjadi kawasan dengan fungsi campuran. Sebagian besar wilayah di Bintaro Jaya banyak mengalami alih fungsi menjadi komersial. Meskipun dalam perencanaannya telah ditetapkan sektor mana sajakah yang dapat diubah menjadi komersial, sedangkan Sektor 9 merupakan kawasan peruntukan perumahan. Berdasarkan permasalah tersebut, penelitian ini akan membahas mengenai tingkat kenyamanan bermukim masyarakat Bintaro Sektor 9 akibat adanya alih fungsi hunian menjadi komersial untuk melihat apakah kawasan perumahan Bintaro Jaya masih memiliki lingkungan yang nyaman untuk ditinggali dan beraktivitas.

\section{KAJIAN PUSTAKA}

Sasono dan Husein (1995) menyatakan bahwa alih fungsi lahan merupakan kegiatan merubah penggunaan lahan dari suatu kegiatan menjadi kegiatan yang lainnya. Perubahan fungsi merupakan hal yang sering terjadi dalam pengembangan kota. Pemanfaatan rumah dapat digunakan sebagai kegiatan usaha secara terbatas tanpa membahayakan dan tidak mengganggu fungsi hunian. Gangguan fungsi hunian dari adanya alih fungsi hunian menjadi komersial akan menimbulkan ketidaknyamanan. Tingkat kenyamanan tidak dapat dilihat secara langsung melainkan melalui pertanyaan langsung kepada individu yang merasakannya secara langsung (Sanders \& McCormick, 1993).

Persepsi akan kenyamanan yang dirasakan tiap masyarakat dapat berbeda-beda mengikuti faktor yang telah atau sedang terjadi di kehidupannya. Menurut Krech dan Richard (dalam Jalaludin, 2011), faktor-faktor yang mempengaruhi persepsi seseorang, meliputi kebutuhan, harapan dan suasana emosinya. Dalam perkembangan permukiman, iklim lingkungan, ekonomi, sosial, budaya dan politik yang sehat akan mempengaruhi kualitas hidup masyarakat yang tinggal di dalamnya. Aspek kenyamanan terdiri dari kenyamanan fisik, psikospiritual, lingkungan dan sosial kultural. Kenyamanan fisik merupakan sensasi yang dirasakan oleh tiap individu (Kolcaba, 2003). Kenyamanan psikospiritual merupakan konsep diri, harga diri, dan makna kehidupan. Kenyamanan lingkungan merupakan kondisi yang dipengaruhi dari luar yang berupa suhu, pencahayaan dan suara (kebisingan). Kenyamanan sosial kultural merupakan hubungan interpersonal antar keluarga, sosial dan masyarakat.

Lingkungan perumahan terdiri atas 4 unsur pembentuk, yaitu ruang kehidupan, jaringan, kontrol individu dan lingkungan (Doxiadis, 1968). Ruang kehidupan dapat dimaknai sebagai keserasian fungsi bangunan yang ada antara hunian dan fasilitas pendukungnya. Jaringan dalam lingkungan perumahan, meliputi sistem sirkulasi dan jalur transportasi. Kontrol individu merupakan perasaan untuk membatasi interaksi dengan orang lain. Sedangkan untuk lingkungan, meliputi kebisingan, polusi udara dan pencahayaan. Kriteria keserasian ruang kehidupan dicapai dengan memepertahankan karakter kawasan, misalnya tidak mengubah fungsi bangunan, mengubah RTH maupun mengurangi lebar sungai/kali. Penataan jaringan pada lingkungan perumahan berkaitan erat dengan sistem sirkulasi kawasan sekitarnya, sehingga kawasan tersebut mudah untuk diakses sebesar-besarnya oleh publik termasuk penyandang cacat dan lanjut usia. Peningkatan sistem penghubung yang ada sesuai pedoman RDTR akan lebih berorientasi pada pejalan kaki. Pemenuhan privasi pada lingkungan yang mengalami alih fungsi akan menghadirkan ruang penghuni rumah untuk menjalankan kegiatannya. Kegiatan usaha atau komersial yang tidak menggangu fungsi hunian adalah kegiatan yang tidak menimbulkan penurunan dari suara, asap atau bau-bauan dan penggunaan lampu dari kegiatan usaha.

\section{METODE PENELITIAN}

Jenis metode penelitian yang digunakan dalam penelitian ini adalah metode kuantitatif. Karakter dalam penelitian kuantitatif adalah fokus penelitian yang rinci dan kaku, dimana dalam prosesnya sesuai alur yang sudah disusun sejak awal menggunakan data terukur (Creswell, 2003). Proses pendekatan yang digunakan merupakan pendekatan deduktif yang digunakan untuk kesimpulan berdasarkan sekelompok premis yang tersedia (Sugiyono, 2018). Penelitian ini menggunakan 4 variabel yang dapat dilihat pada Tabel 1.

Populasi dari penelitian ini adalah satuan KK (Kepala Keluarga) yang dikurangi pertokoan. Sampel yang diambil berjumlah 100 responden menggunakan teknik quota sampling. Dalam menentukan skala yang digunakan dalam kuesioner ini adalah skala semantik diferensial, yang biasa digunakan untuk mengatur pendapat dan persepsi seseorang tentang fenomena yang ingin diteliti (Jakaria, 2015). Skala ini digunakan untuk mengukur sikap dan persetujuannya dalam pertanyaan kuesioner dengan jawaban yang telah tersusun satu garis kontinu "sangat setuju" dan "sangat tidak 
setuju". Responden yang digunakan dalam penelitian ini merupakan masyarakat perumahan yang telah tinggal lebih dari 5 tahun dan bukan pemilih usaha yang ada di perumahan.

Tabel 1. Variabel dan Subvariabel

\begin{tabular}{cl}
\hline Variabel & \multicolumn{1}{c}{ Subvariabel } \\
\hline Kompatibilitas & Kesesuaian Fungsi Komersial \\
Aksesibilitas & Akses Keluar Masuk \\
Privasi & Fungsi Pedestrian \\
& Privasi Ruang Personal \\
& $\begin{array}{l}\text { Polusi Udara (aroma dan bau) } \\
\text { Kualitas Lingkungan } \\
\end{array}$ \\
& Kebisingan \\
& Pencahayaan \\
\hline
\end{tabular}

Selain menggunakan kuesioner, peneliti juga melakukan wawancara dengan 36 narasumber yang merupakan masyarakat perumahan untuk setiap RT. Narasumber yang dipilih merupakan tokoh masyarakat, seperti RT dan masyarakat yang sudah tinggal di lingkungan sejak awal perumahan didirikan. Penelitian tingkat kenyamanan bermukim ini dilakukan di kompleks perumahan Maleo dan Kasuari yang masuk ke dalam kawasan Bintaro Sektor 9. Pemilihan lokasi penelitian ini dikarenakan dua perumahan ini merupakan kawasan dengan masalah alih fungsi hunian menjadi komersial paling banyak di Sektor 9. Gambar 1 adalah Peta Batas Wilayah Penelitian dan Persebaran Responden.

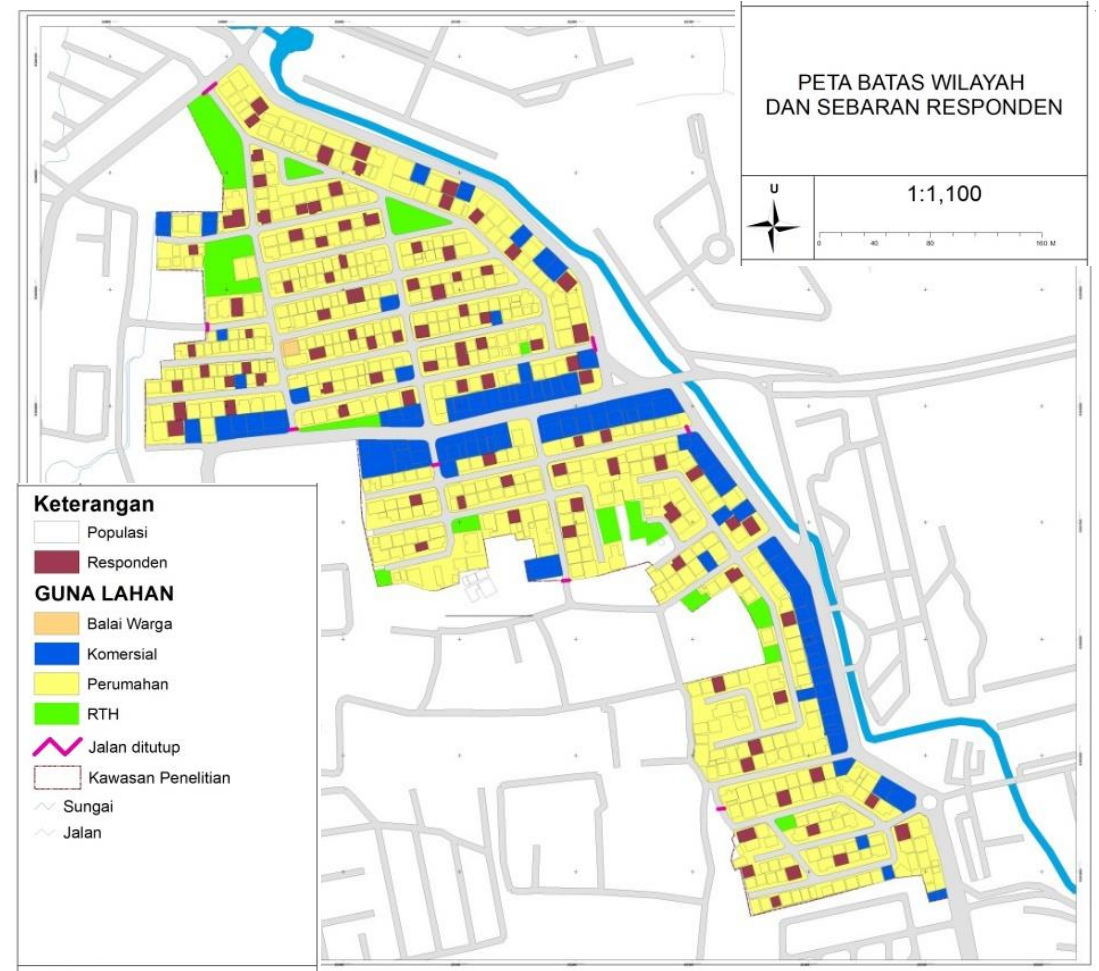

Gambar 1. Peta Batas Wilayah dan Persebaran Responden

Teknik analisis yang digunakan untuk variabel ini adalah analisis skoring. Tiap satuan variabel memiliki nilai yang sama dengan standar yang telah ditentukan dalam skoring. Dalam melakukan analisis statistik, perbedaan jenis data sangat berpengaruh terhadap pemilihan model atau alat uji statistik. Skala interval mempunyai karakteristik seperti yang dimiliki oleh skala nominal dan ordinal dengan ditambah karakteristik lain, yaitu berupa adanya interval yang tetap (Suryabrata, 2003). Kategori tingkat kenyamanan bermukim dibagi menjadi 3 dengan pembagian menggunakan rumus berikut.

Banyak kelas $=1+3,33 \log n$

Dimana, $\mathrm{n}$ adalah banyak kelas dalam penelitian

Banyak kelas $=1+3,33 \log 3=2,59$ dibulatkan ke atas menjadi 3

Klasifikasi dilakukan dengan menggunakan rumus interval: 


$$
K=\frac{\mathrm{a}-\mathrm{b}}{\mathrm{u}}
$$

$\mathrm{K} \quad$ : interval kelas

a : skor tertinggi

b : skor terendah

u : jumlah kelas yang diinginkan

Untuk mendapatkan kelas yang seimbang, maka peneliti perlu mengetahui jarak atau selisih antar kelas yang akan dibuat. Jika skor tertinggi adalah 7 dan skor terendah adalah 1, maka kemudian skor tersebut dapat dimasukan ke dalam rumus:

$$
\begin{gathered}
K=\frac{7-1}{3} \\
K=2
\end{gathered}
$$

Berdasarkan perhitungan di atas maka didapatkan interval setiap kelas adalah 2. Dengan demikian interval kelas untuk gangguan yang dirasakan masyarakat perumahan berdasarkan hasil kuesioner sebagai berikut.
a. Tidak ada gangguan $:>500$ (Nyaman)
b. Gangguan rendah : 300-500 (Kurang Nyaman)
c. Gangguan tinggi : :100-300 (Tidak Nyaman)

Hasil analisis skoring yang terbentuk kemudian dipetakan dalam ArcGIS untuk melihat pola kenyamanan bermukim yang dirasakan oleh masyarakat. Radius yang ditentukan dalam membentuk pola adalah 50 meter dari hunian responden dan terletak pada ruas jalan yang sama. Setelah terbentuk pola kenyamanan berdasarkan hasil kuesioner, wawancara digunakan untuk mencocokan alih fungsi yang terjadi benar-benar mengubah kenyamanan bermukim masyarakat sekaligus memperkaya hasil penelitian.

\section{HASIL DAN PEMBAHASAN}

Tingkat gangguan alih fungsi lahan perumahan menjadi komersial terhadap kenyamanan bermukim dapat dilihat dari aspek kompatibilitas, aksesibilitas, privasi dan kualitas lingkungan. Aspek kompatibilitas diidentifikasi dengan melihat kesesuaian fungsi komersial, aspek aksesibilitas diidentifikasi dari kemudahan untuk keluar masuk perumahan dan fungsi pedestrian, aspek privasi diidentifikasi dari tingkat privasi personal individu dengan lingkungannya, dan aspek kualitas lingkungan diidentifikasi dari pencahayaan (lampu), polusi udara (asap kendaraan) dan polusi udara

\begin{tabular}{|c|c|c|c|c|c|c|}
\hline Variabel & Subvariabel & Skala & Persentase Masyarakat (\%) & Total $(\%)$ & Skor & Keterangan \\
\hline \multirow[t]{7}{*}{ Kompatibilitas } & Kesesuaian Fungsi & 7 & 16 & 100 & 453 & Kurang \\
\hline & Komersial & 6 & 20 & & & Nyaman \\
\hline & & 5 & 16 & & & \\
\hline & & 4 & 16 & & & \\
\hline & & 3 & 13 & & & \\
\hline & & 2 & 14 & & & \\
\hline & & 1 & 5 & & & \\
\hline \multirow[t]{11}{*}{ Aksesibilitas } & Akses Keluar Masuk & 7 & 1 & 100 & 309 & Kurang \\
\hline & & 6 & 14 & & & Nyaman \\
\hline & & 5 & 4 & & & \\
\hline & & 4 & 14 & & & \\
\hline & & 3 & 21 & & & \\
\hline & & 2 & 22 & & & \\
\hline & & 1 & 24 & & & \\
\hline & Fungsi Pedestrian & 7 & 1 & 100 & 350 & Kurang \\
\hline & & 6 & 3 & & & Nyaman \\
\hline & & 5 & 16 & & & \\
\hline & & 4 & 32 & & & \\
\hline
\end{tabular}
(kebisingan).

Tabel 2. Hasil Kuesioner Persepsi Kenyamanan Bermukim 


\begin{tabular}{|c|c|c|c|c|c|c|}
\hline Variabel & Subvariabel & Skala & Persentase Masyarakat (\%) & Total (\%) & Skor & Keterangan \\
\hline & & 3 & 25 & & & \\
\hline & & 2 & 20 & & & \\
\hline & & 1 & 3 & & & \\
\hline \multirow[t]{7}{*}{ Privasi } & Privasi Ruang & 7 & 14 & 100 & 452 & Kurang \\
\hline & Personal & 6 & 26 & & & Nyaman \\
\hline & & 5 & 16 & & & \\
\hline & & 4 & 17 & & & \\
\hline & & 3 & 12 & & & \\
\hline & & 2 & 10 & & & \\
\hline & & 1 & 6 & & & \\
\hline Kualitas & Polusi Udara (aroma & 7 & 0 & 100 & 236 & Tidak \\
\hline \multirow[t]{20}{*}{ Lingkungan } & dan bau) & 6 & 5 & & & Nyaman \\
\hline & & 5 & 0 & & & \\
\hline & & 4 & 11 & & & \\
\hline & & 3 & 20 & & & \\
\hline & & 2 & 38 & & & \\
\hline & & 1 & 26 & & & \\
\hline & Kebisingan & 7 & 15 & 100 & 454 & Kurang \\
\hline & & 6 & 22 & & & Nyaman \\
\hline & & 5 & 12 & & & \\
\hline & & 4 & 21 & & & \\
\hline & & 3 & 17 & & & \\
\hline & & 2 & 9 & & & \\
\hline & & 1 & 4 & & & \\
\hline & Pencahayaan & 7 & 1 & 100 & 318 & Kurang \\
\hline & & 6 & 5 & & & Nyaman \\
\hline & & 5 & 8 & & & \\
\hline & & 4 & 31 & & & \\
\hline & & 3 & 16 & & & \\
\hline & & 2 & 30 & & & \\
\hline & & 1 & 9 & & & \\
\hline
\end{tabular}

Analisis tingkat kenyamanan bermukim dilakukan dengan memetakan hasil skoring yang telah dilakukan. Berdasarkan hasil pemetaan, kompatibilitas kegiatan komersial pada kawasan terhadap kebutuhan masyarakat adalah kurang nyaman. Hal ini dikarenakan sebagian besar fungsi komersial yang ada di lingkungan perumahan tidak memberikan banyak manfaat bagi kehidupan masyarakat. Jenis komersial yang banyak memberi manfaat adalah apotek, toko buku/ATK dan minimarket. Toko-toko tersebut dinilai dapat mempermudah masyarakat dalam memenuhi kebutuhannya karena dapat lebih mudah dijangkau. Namun terdapat juga jenis-jenis komersial yang dianggap mengganggu dan tidak sesuai dengan kebutuhan dan dinilai mengganggu.

Hasil analisis skoring kenyamanan untuk kemudahan akses masyarakat perumahan adalah kurang nyaman. Sebagian besar masyarakat merasa akses untuk keluar masuk lingkungan terganggu sejak tumbuhnya komersial. Selain itu, fungsi pedestrian sebagai jalur bagi pejalan kaki banyak hilang dan beralihfungsi sebagai lahan parkir (Gambar 2). Dengan adanya gangguan akses keluar masuk dan fungsi pedestrian ini menjadikan lingkungan ramai, kepadatan di beberapa titik dan masyarakat kesulitan untuk beraktivitas.
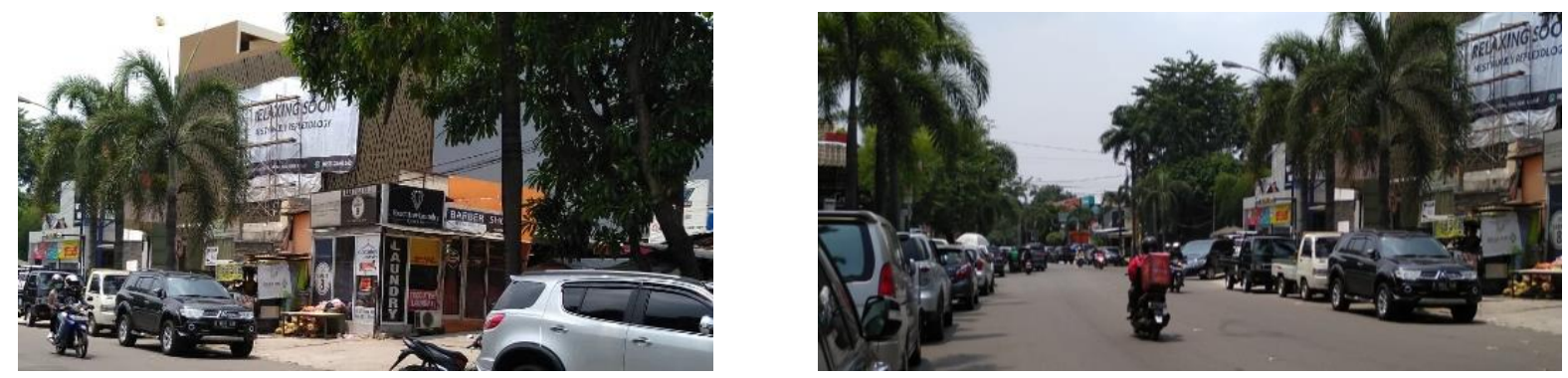

Gambar 2.Gangguan Aksesibilitas oleh Penggunaan Badan Jalan dan Jalur Pejalan Kaki sebagai Area Parkir 
Tingkat kenyamanan privasi ruang personal masyarakat setelah dilakukan analisis skoring adalah kurang nyaman. Gangguan yang dirasakan disebabkan oleh keberadaan kafe/ resto dan jasa kecantikan. Jenis komersial tersebut dirasa paling menggangu karena lokasinya yang tidak hanya berada di sepanjang jalan besar saja, tetapi masuk hingga ke dalam kompleks perumahan. Pengurangan privasi yang terjadi pada kawasan perumahan lebih bertumpu pada banyaknya orang asing yang berlalu lalang di dekat tempat tinggalnya (Gambar 3b) dan secara tidak langsung melihat masyarakat sekitar melakukan kegiatan yang sifatnya pribadi (overlooking). Sehingga, kehidupan masyarakat perumahan akan lebih terlihat oleh orang-orang asing yang melakukan kegiatan di komersial tersebut.

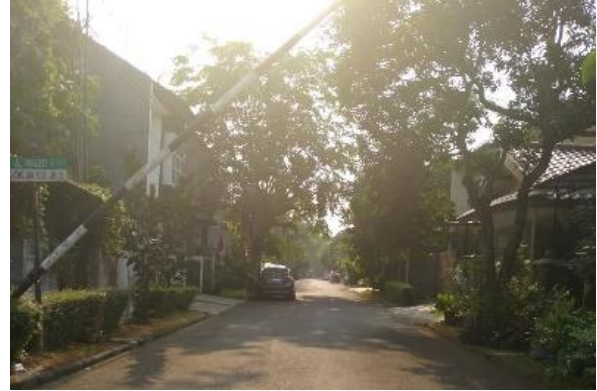

(a)

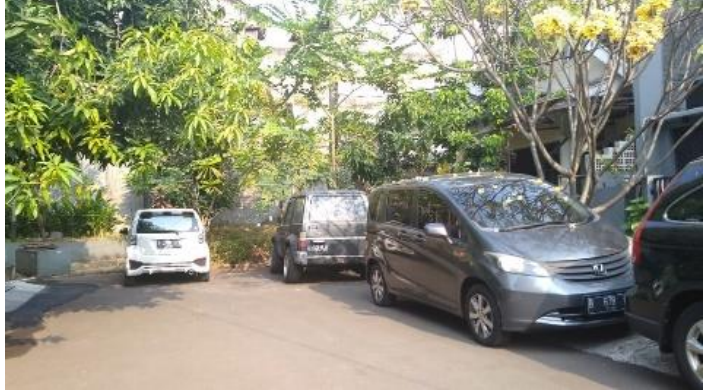

(b)

Gambar 3. (a) Usaha Masyarakat Menjaga Kualitas Lingkungan; (b) Masuknya Orang-Orang Asing di Dalam Perumahan

Alih fungsi hunian menjadi komersial juga menimbulkan gangguan bagi kualitas lingkungan perumahan. Berdasarkan hasil analisis yang dilakukan, kualitas lingkungan kawasan perumahan Bintaro Sektor 9 adalah tidak nyaman. Berdasarkan hasil skor polusi udara kecenderungannya adalah tidak nyaman, namun masyarakat perumahan sudah memiliki kesadaran untuk menjaga kualitas lingkungannya agar tetap nyaman dan asri dengan memanfaatkan lahan kosong untuk tanaman buah, vertical garden, bank sampah dan komposting (Gambar 3a). Pengelolaan tumbuhan dan pepohonan di kawasan juga diharapkan akan mengurangi polusi udara yang terjadi saat ini.

Kebisingan yang timbul dari kegiatan komersial di sekitar kawasan dirasa kurang nyaman, hal ini dipengaruhi oleh jenisnya yang beragam dan jarak yang sangat dekat dengan hunian. Hal ini sejalan dengan yang dikatakan oleh Bapak Restu dan Bapak Husein selaku masyarakat perumahan yang merasakan perubahan kenyamanan lingkungan sejak adanya alih fungsi. Kebisingan yang muncul dikarenakan lokasi komersial yang berdekatan dengan hunian yang berada tepat di belakangnya. Tingkat kebisingan juga dirasa meningkat saat sore menjelang malam hari dan akhir pekan dimana akan semakin banyak orang yang datang.

Sedangkan pencahayaan yang digunakan oleh kegiatan komersial dirasa kurang nyaman. Gangguan ini muncul dikarenakan kecerahan lampu yang digunakan oleh komersial lebih terang saat malam hari. Setelah mengetahui tingkat kenyamanan pada masing-masing faktor, hasil akhir kenyamanan bermukim pada kawasan perumahan Bintaro Sektor 9 adalah kurang nyaman dengan kecenderungan tidak nyaman (Tabel 3 dan Gambar 2).

Tabel 3. Tabel Analisis Kenyamanan Bermukim Perumahan Bintaro Sektor 9

\begin{tabular}{cccc}
\hline Aspek & Komponen & Kelas & Keterangan \\
\hline Aksesibilitas & Akses Keluar Masuk & 2 & Kurang Nyaman \\
& Fungsi Jalur Pedestrian & 2 & Kurang Nyaman \\
Kualitas & Kebisingan & 2 & Kurang Nyaman \\
Lingkungan & Pencahayan & 2 & Kurang Nyaman \\
& Polusi Udara & 1 & Tidak Nyaman \\
Kompatibilitas & Kesesuain fungsi & 2 & Kurang Nyaman \\
Privasi & Ruang personal & 2 & Kurang Nyaman \\
& Total & 13 & \\
& Rata-rata & 1,86 & Tidak Nyaman \\
\hline
\end{tabular}






Gambar 4. Peta Kenyamanan Bermukim Masyarakat Bintaro Sektor 9

\section{KESIMPULAN}

Alih fungsi hunian menjadi komersial di Bintaro Sektor 9 yang telah terjadi lebih dari 20 tahun mempengaruhi kenyamanan bermukim masyarakat. Masyarakat merasa penurunan kenyamanan jika dibandingkan saat pertama kali menempati rumahnya. Penurunan kenyamanan yang paling dirasakan adalah kualitas lingkungan, dimana munculnya bau-bauan dan polusi dari kendaraan bermotor. Kendaraan bermotor yang beraktivitas di kawasan perumahan Bintaro sektor 9 juga menimbulkan kemacetan dan pengurangan fungsi pedestrian. Selain gangguan kenyamanan fisik seperti di atas, terdapat gangguan sosial privasi masyarakat. Privasi personal dirasa kurang nyaman dikarenakan banyaknya komersial yang berkembang masuk ke dalam kompleks perumahan. Sebagian besar komersial yang berkembang di perumahan Bintaro Sektor 9 juga dirasa kurang memberikan manfaat. Belum adanya kerja sama antara pemerintah dan pengelola kawasan dalam mengendalikan pemanfaatan ruang di kawasan perumahan menjadikan pertumbuhan komersial tidak terkendali dan menurunkan kenyamanan bermukim masyarakat di Bintaro Sektor 9 .

\section{DAFTAR PUSTAKA}

Budiharjo, E. (1987). Percikan Gagasan tentang Arsitektur Perumahan dan Perkotaan. Yogyakarta : Gajah Mada University Press. Creswell, J. W. (2003). Research Design Qualitative, Quanitative and Mixed Methods Approches (2nd ed.) New Delhi: Sage Publications.

Doxiadis, C. A. (1968). EKISTICS An Introduction To The Science Of Human Settlements. London: Hutchinson of London. Husein, A.. S dan Sasono, A. (1995). Ekonomi Politik Penguasaan Tanah. Jakarta: Pustaka Sinar Harapan. Jakaria, Y. (2015). Mengolah Data Penelitian Kuantitatif Dengan SPSS-Aplikasi Data Pendidikan. Bandung: Alfabeta. Jalaluddin, R. (2011). Psikologi Komunikasi. Bandung: PT. Remaja Kolcaba, K. (2003). Comfort Theory and Practice: A Vision For Holistic Health Care And Research. New York: Springer Publishing Company

Sanders, M.S. \& McCormick, E. J. (1993). Human factors in engineering and design (7th ed.). Mcgraw-Hill Book Company Sugiyono. (2018). Metode Penelitian Kuantitatif. Bandung: Alfabeta Suryabrata, S. (2003). Metode Penelitian. Jakarta: PT. Raja Grafindo Persada 